Version accepted for publication in Aquatic Conservation: Marine and Freshwater Ecosystems

\title{
Re-introduction of structurally complex wood jams promotes channel and habitat recovery from overwidening: implications for river conservation
}

\author{
Gemma L Harvey, Alexander J Henshaw, Chris Parker, Carl D Sayer
}

\section{ABSTRACT}

1. Large wood is a powerful geomorphic agent in rivers, providing important habitat functions for a range of aquatic organisms, but has been subject to a long history of removal.

2. Internationally, approaches to river restoration are increasingly incorporating large wood features, but generally favour simple flow deflectors (e.g. single logs, stripped of branches and anchored in place) over more complex structures that more accurately mimic natural wood jams.

3. This paper explores channel response to wood-based restoration of an overwidened lowland chalk stream that incorporated whole felled trees. Hydraulics, sediment, topography and vegetation data were assessed for a three year period for two restored reaches: an upstream reach where pre-restoration baseline data were obtained, and a downstream reach restored prior to data collection.

4. Where pre-restoration data were available, the introduction of wood jams generated sediment deposition within jams leading to the development of vegetated marginal 'benches' and bed scour in adjacent areas of flow convergence. Patterns were less clear in the downstream reach, where restoration design was less ambitious and outcomes may have been impacted by subsequent restoration work upstream.

5. The results indicate that reintroduction of large wood (whole trees), can promote channel and habitat recovery from overwidening in lowland rivers, creating important ecological benefits through the provision of structurally complex marginal habitat and associated food 
resources. Longer-term assessments are required to establish whether the trajectories of change are persistent.

6. The work emphasises the effectiveness of restoration approaches that aim to 'work with nature'. The ambitious design, incorporating structurally complex wood jams, was also lowcost, using materials available from the river corridor (existing riparian trees). Furthermore, ecosystem engineering effects were amplified by the colonisation of wood jams by aquatic vegetation. The approach should, therefore, be transferable to other lowland rivers, subject to wider catchment constraints.

\section{KEYWORDS (6-10):}

River, stream, restoration, catchment management, vegetation

\section{INTRODUCTION}

Large wood is a natural feature and critical component of wooded river systems throughout the world (Gregory et al., 2003) and exerts a significant influence on fluvial processes and aquatic biota across multiple scales. Instream large wood has the potential to act as a powerful geomorphic agent in river systems by initiating and maintaining a range of fluvial landforms (Keller and Swanson, 1979; Gregory and Davis, 1992; Gurnell et al., 1995; Collins et al., 2012) and has an important ecological role, including provision of habitat and food resources for aquatic organisms such as fish and invertebrates (e.g. Benke et al., 1985; Gibbons, 1990; Cashman et al., 2016) and nutrient attenuation (Krause et al., 2014). Despite these important contributions to hydrogeomorphological, ecological and biogeochemical processes, large wood has been subject to widespread removal across the world, particularly from lowland rivers (Gippel et al., 1996) which include distinctive, globally rare and internationally important habitats such as chalk streams (Mainstone, 1999). Wood removal from lowland rivers has occurred both indirectly through woodland clearance for floodplain development over longer timescales of $10^{3}$ years (Watts, 2006; Magilligan et al., 2008), and more recently (largely over timescales of $10^{2}$ years) through flow regulation and embankment (Nakamura and Swanson, 
2003; Erskine and Webb, 2003) and the direct and deliberate removal by dredging and 'desnagging' to maintain channel capacity and reduce the possibility of blockages at structures (Gippel et al., 1996; Erskine and Webb, 2003). Recent decades have seen increasing emphasis at the international level on improving the ecological status of water bodies (e.g. the Water Framework Directive; European Parliament, 2000) and conserving key ecosystem services (Millenium Ecosystem Assessment, 2005). This has encouraged an increase in the use of large wood in river restoration projects, in particular across Europe, the USA and Australia (Gibbons, 1990; Larson et al.,2001; Erskine and Webb, 2003; Kail et al., 2007; Cashman, 2015) as a means of improving the biodiversity and conservation value of lowland rivers that have been subjected to historical pressures including physical modification, abstraction, agriculture and urbanisation.

Instream large wood is defined as living or dead wood $>1 \mathrm{~m}$ length and $>10 \mathrm{~cm}$ diameter (Thevenet et al., 1998). Naturally occuring wood jams, comprising multiple wood pieces of varying size and arrangement, can be highly complex in structure and vary according to channel style and dimensions (Gurnell et al., 2002). These range from channel-spanning energy dissipating structures in smaller streams (e.g. Wallerstein and Thorne, 2004), to partial jams in larger single-thread channels where wood length is smaller than channel width (Abbe and Montgomery, 1996), to large pioneer islands developed around flood-deposited trees in multi-thread channels (Gurnell et al., 2001; 2005). The introduction of wood as part of a river restoration programme should, therefore, ideally integrate rehabilitation of the riparian zone to an extent where natural processes of large wood recruitment can take place (Erskine and Webb, 2003; Roni et al., 2015). In practice, however, this process is typically accelerated by the installation of instream wood structures in order to satisfy shorter-term habitat goals (Gippel et al., 1996; Erskine and Webb, 2003). Restoration design must seek to balance hydrogeomorphological and ecological goals with concerns over flood and erosion risks, as well as public perceptions around naturalness, safety and aesthetics (Piégay et al., 2005; Chin et al., 2008; Wyzga et al., 2009; Wohl, 2015). Thus the use of wood in river restoration remains 
somewhat controversial (Roni et al., 2015), highlighting a pressing need for further research to generate an improved evidence base.

To date, there has been a tendency for the design of restored wood jams to reflect blockage concerns as opposed to key habitat factors (Gippel et al., 1996) and to favour simple, flow deflectors or groynes (e.g. single logs without branches, often anchored in place) over natural wood and more structurally complex jams with multiple pieces and intact branches (Thompson and Stull, 2002; Cashman, 2015) even though failure rates (i.e. through dislodgement) of placed wood are relatively low (Roni et al., 2015). As a result, restored wood jams tend to differ considerably in their size, spacing and orientation relative to the potential natural state (Kail et al., 2007). Importantly, flow deflectors and groyne structures do not mimic the wood jams generated by natural fallen trees and therefore the execution of this type of wood-based restoration may not optimise outcomes. Indeed, many of common restoration approaches to increasing structural complexity, including installation of wood and other structures such as boulders, have generally failed to deliver significant increases in biodiversity (Palmer et al., 2010). Questions remain regarding the effectiveness of introduced wood in altering flow hydraulics and channel morphology (Larson et al., 2001; Thompson and Stull, 2002; Cashman, 2015), although even very simple (natural) wood structures have been shown to promote both hydromorphological heterogeneity and macroinvertebrate diversity in pristine lowland systems (Pilotto et al., 2014; 2016). Given the increased investment in restoration projects (Bernhardt et al., 2005) and the notorious deficiencies in post-project river restoration appraisal (Kail et al., 2007; Morandi et al., 2014), there is a pressing need for improved understanding of river channel responses (morphological, habitat, ecological) to restoration approaches using more complex large wood structures.

In modified catchments introduced wood may play a different role. For example, ecosystem engineering (sediment trapping) by plants and trees can generate marginal bench-like landforms in overwidened rivers, leading to channel contraction or narrowing (Erskine et al., 
2012; Gurnell et al., 2014). This suggests that introduction of large wood pieces in river restorations may be able to assist channel recovery from historic modifications, reducing the need for more costly bioengineering approaches to the improvement of hydromorphological diversity and ecological status. Approaches which seek to mimic more closely natural processes such as tree fall also complement wider evolving environmental management and conservation agendas such as 'working with natural processes' (Environment Agency, 2010) and 're-wilding' (Navarro and Pereira, 2012).

This paper explores whether large wood can promote channel recovery from overwidening in lowland rivers, focusing on a restoration design incorporating whole trees in the form of partial wood jams that was implemented to improve the conservation and biodiversity value of a chalk stream in eastern England. The site is located upstream of the Bure Valley Living Landscape encompassing a series of Sites of Special Scientific Interest (SSSI) and a range of important wetland habitats. The site is therefore representative of rare and important chalk stream habitats; situated in a catchment of conservation importance but exposed to numerous pressures from historic physical modifications, over abstraction, pollution and agriculture (O'Neill and Hughes, 2014). We hypothesised that the introduced partial wood jams would:

1. Promote the accumulation of fine sediment at channel margins around wood jams, leading to the development of marginal sediment benches and intervening areas of flow concentration between jams.

2. Facilitate the areal expansion of marginal and emergent vegetation through marginal bench development.

\section{METHODS}

\section{Field site and restoration design}


The research site was located on the River Bure, a lowland chalk stream in north Norfolk, eastern England (Figure 1). Upstream catchment land use is predominantly arable agriculture and the floodplain at the study section comprises wet Alder (Alnus glutinosa) Carr woodland. The river channel in the vicinity of the study site has been heavily modified since c.1900 by the development of four mills, altering channel planform (realignment and widening) to increase conveyance and holding capacity. As a result, many reaches are overwidened and heavily silted. There is a patchy wooded riparian zone but large wood has historically been removed from the channel as part of flood maintenance work. The study section was located at an altitude of approximately $12 \mathrm{~m}$ AOD. Bankfull width was approximately $8-10 \mathrm{~m}$, and depth approximately $1 \mathrm{~m}$. Bed sediment ranged from silt to gravel but was generally fine: average $D_{50}$ 1-2 phi for characteristic bare sediment patches is reported in Osei et al. (2015).

Between 2008 and 2010, river restoration works were designed and implemented by the National Trust in response to concerns over a declining population of wild brown trout (Salmo trutta); a problem that affects approximately one third of chalk streams (O'Neill and Hughes, 2014). The project sought to enhance physical habitat by reinstating large wood features, with the underlying aim of restoring a 'natural process'. Riparian trees ( $A$. glutinosa) were felled into the river from the wooded riparian zone and modified as necessary to comply with UK Environment Agency by-laws and angling access. Full details of the approach can be found in the UK River Restoration Centre's manual of techniques (River Restoration Centre, 2013).

The study area comprised a stretch with four wood jams installed in 2008 (reach R1) and a stretch with seven jams installed in 2010 (reach R2), with each reach approximately $60 \mathrm{~m}$ in length. A high dam (channel-spanning log) upstream of section R1 formed naturally and was therefore not assessed as part of the restored reach. All jams included in the data set were classed as 'partial jams' (Gregory et al., 1985) since they did not span the full channel width. Some key parameters (slope, fine sediment accumulation, vegetation cover) were also assessed for an additional $60 \mathrm{~m}$ long unrestored reach upstream (NR) to help distinguish 
wood-induced change from wider catchment-induced changes. In general, R2 jams were generally larger and less spatially discrete than $\mathrm{R} 1$ jams, reflecting a more ambitious second phase of the restoration works (see Figure 1). Key wood jam properties are provided in Table 1.

\section{Field methods}

Field data were captured over a three year period (2010 - T1, 2011 - T2 and 2012 - T3). For $\mathrm{R} 1$ this provides data for 2-4 years following restoration work, and for R2 it includes prerestoration baseline data and two years of post-restoration data. To provide hydrological context for the study period, pressure transducers (Solinst Levelogger Gold) were installed to provide continuous flow stage records at 15 minute intervals in each reach (R1, R2, NR). Stage data (elevation in $\mathrm{m}$ above an arbitrary datum) were corrected for atmospheric pressure using a Solinst Barologger installed on the floodplain. Mean daily discharge $(Q)$ data were also available for a gauging station located $2.5 \mathrm{~km}$ downstream of the research site at Ingworth (National River Flow Archive, undated), although there is a small tributary input (Scarrow Beck) between the research site and this gauging station. The logger at $\mathrm{R} 2$ was dislodged during the restoration work but was reinstated in the same location nine days later.

Hydrogeomorphological data were collected using a series of regularly spaced cross sections (every $5 \mathrm{~m}$ ) since wood locations for R2 were unknown at the time of baseline surveys. For all variables, except bed elevation, measurements were taken at four equally spaced locations across each transect $(n=60$ point measurements per reach) and surveys were conducted at the start of the vegetation growth season (April/May) and during the period of peak growth (July/August). For cross sections in R1 and R2, points were additionally assigned to 'wood' patches where point measurements fell within the extent of wood jams and to 'flow' patches where points fell within areas of flow concentration between jams (as identified through visual mapping; see Figure 1). In order to quantify the accumulation of surficial fine sediment, point measurements were undertaken by inserting a $2 \mathrm{~mm}$ diameter metal rod into the bed at 
constant pressure until the coarse underlying substrate was encountered (Lisle and Hilton, 1992).

In order to explore changes in flow conditions within and between jams, flow velocity was recorded (for the same cross sectional grid) using a SonTek/YSI Flowtracker handheld Acoustic Doppler Velocimeter (ADV®) averaged over $30 \mathrm{~s}$. Mean daily $Q$ at Ingworth was between 0.77-1.20 $\mathrm{m}^{3} \mathrm{~s}^{-1}\left(\sim \mathrm{Q}_{75}-\mathrm{Q}_{45}\right)$ and measured $\mathrm{Q}$ at the study site was between 0.47 $0.64 \mathrm{~m}^{3} \mathrm{~s}^{-1}$ across the surveys and hence there was some variation in flow conditions between surveys. Flow depth and visual assessment of the dominant substrate category (silt, sand, or gravel; identified for a $1 \mathrm{~m}^{2}$ area around the flow depth sampling point) were also recorded for each sampling location. An estimate of the local boundary shear stress $\tau_{o}$ at each sampling location was made using the flow depth $h$, the mean flow velocity $U$ and an estimate of bed roughness $z_{0}$ in a flow resistance relation following Wilcock et al. (1996):

$$
\frac{U}{u_{*}}=\frac{1}{K} \ln \left(\frac{h}{e z_{0}}\right)
$$

where $u_{*}$ is the bed shear velocity $\left(=\left[\tau_{0} / \rho\right]^{1 / 2}\right), \rho$ is water density, $K$ is von Karman's constant $(0.4), e$ is the base of natural logarithms and $z_{0}$ is estimated as a function of visual estimates of bed substrate size $\left(=0.095 D_{90}\right)$. The estimated values of $\tau_{o}$ provide an indication of the relative intensity of the local hydraulic environment that is comparable across the surveys. The percentage change in streamwise velocity between paired adjacent margincentre sampling points on each cross section was computed in order to explore the concentration of flow in central channel areas between jams.

To capture the nature of cross sectional morphological changes and derive channel centreline slope, bed elevation cross sections at $5 \mathrm{~m}$ intervals were captured in April of each year using a Leica TPS800 total station. Cross sectional resolution was varied to capture breaks in slope. The location of key wood pieces in each wood jam were also surveyed and these remained in place for the duration of the research period. 
In order to capture changes in vegetation cover and types, presence/absence of vegetation was recorded for each point measurement. Additional detailed field mapping of aquatic and marginal vegetation (to species level) was undertaken in NR, R1 and R2 during peak vegetation growth (July/August). Field sketches of in-river and marginal plant structure were made with reference to a gridded template of the digitised river reaches assisted by marker posts (corresponding to grid points) positioned at $10 \mathrm{~m}$ intervals along both river banks. Resultant maps of vegetation were then digitised in ArcGIS 10.2 and used to both visualise the spatial organisation of different plant species and to estimate their aerial cover. A plant species list together was also generated for each individual wood jam. Environmental indicator values representing the ranges of light, moisture, $\mathrm{pH}$, nitrogen and salt required by vascular plants have been identified for the British flora based on the European Ellenberg system (Hill et al., 1999). The Ellenberg moisture scale was used to identify moisture tolerance ranges of aquatic plants observed in the three reaches and any changes following restoration, in order to indicate the types of species present. Each species was assigned an indicator value for moisture conditions from the range 1 (extreme dryness) to 12 (submerged plants, permanently or almost constantly under water) using species lists published in Hill et al. (2004). The channel in the NR section had lower levels of shading which limited the extent of direct comparison with restored reaches in relation to vegetation data.

\section{Data analysis}

Since data were not normally distributed, non-parametric statistical tests were employed. Mann Whitney $U$ tests were used to explore differences between two groups (e.g. wood and flow patches) and Kruskal Wallis tests to explore differences between more than two groups (e.g. reaches and time periods). For vegetation data, areal coverage of different species was estimated by quantifying spatial coverage in digitised maps (ArcGIS v. 10.2). 


\section{RESULTS}

\section{Sediment accumulation and bench development}

Hydrological time series for the period of record are given in Figure 2. A period of high flows (> $Q_{10}$ ) occurred in autumn/winter 2010-2011 following the R2 restoration in November 2010. This contrasts with moderate flows during the following winter period $(2011 / 12)$ as a result of dry weather conditions. Spring/Summer 2012 was unusually wet resulting in two high flow (> $Q_{10}$ ) events towards the end of the study period. The flows with the greatest capacity for geomorphic change were therefore likely to be those occurring in the period immediately following the $\mathrm{R} 2$ restoration and at the end of the study period.

Surficial fine sediment storage was higher in the two restored reaches relative to the unrestored section (NR), and was higher for R1 compared to R2 throughout the period of record (Figure 3a) and these differences were significantly different $(R 1>R 2>N R$ across the study period; Kruskal Wallis $P<0.01$ ). All three reaches also showed an overall increase in fine sediment storage throughout the period, with more pronounced increases within the restored reaches relative to NR. For R1 there was a pronounced increase in fine sediment depths between T1 and T2 (i.e. following restoration upstream in R2) which is statistically significant (Kruskal Wallis $\mathrm{P}<\mathrm{P} 0.05)$. Channel centreline slope throughout the whole study section decreased from 0.0017 to 0.0015 between T1 and T3 supporting a faster rate of aggradation in the most downstream (R1) section relative to upstream (NR). The percentage of fine sediment stored in wood patches compared to other channel areas was computed from point measurements and showed no trend through time for R1, but increased linearly from $\sim 30 \%$ to $40 \%$ between $\mathrm{T} 1$ and $\mathrm{T} 2$ in R2 (Figure $3 \mathrm{~b}$ ).

Fine sediment depth and shear stress values were examined for wood patches and adjacent patches of deflected flow (see Figure 1) in R1 and R2, comparing T1 and T3 (Figure 4). While there was considerable variability in fine sediment depth and shear stress for both patch types, median values and interquartile ranges indicate deeper sediments and lower shear stress 
within jams relative to adjacent flow patches for $\mathrm{R} 1$ for both time periods and an increase in fine sediment depth within both patch types through time. For R1, statistically significant differences (Mann Whitney $\mathrm{P}<0.05$ ) between the two patch types were identified for $\mathrm{R} 1$ for fine sediment depth (T1 spring and summer) and shear stress (all surveys except summer T1/T3). For R2, prior to wood installation, fine sediment depth and shear stress were similar between marginal and central channel areas, but following restoration the patch types indicated more distinct sheltered depositional environments around the wood jams and areas of higher shear stress and lower fine sediment depths in adjacent flow deflection patches, although these differences were not statistically significant (Mann Whitney $U P>0.05$ ), reflecting high spatial variability. The percentage change in streamwise velocity between paired adjacent wood and flow patches in R2, where pre-restoration data were available (Figure 4), shows an increase in concentration of flows in central channel areas (higher \% increase in velocity) following restoration but with considerable variability in space and through time which may in part reflect the differences in flow conditions between surveys (see Methods section). Smaller differences in velocities between marginal and central channel areas were evident for the summer surveys when vegetation cover was highest.

Cross section profiles comparing T1 and T3 for each wood jam are presented in Figures 5 and 6. For 7 out of 11 wood jams, cross sectional profiles showed increased bed elevations in marginal areas around the wood jams (increasing by between $0.1-0.3 \mathrm{~m}$ and extending 2.5 - $5 \mathrm{~m}$ from the banks) and scour in adjacent areas where flow was concentrated between jams (between approximately $0.05 \mathrm{~m}$ and $0.3 \mathrm{~m}$ at the deepest point). The close proximity of jams and positioning of key pieces along both banks also introduces difficulties in separating the interacting effects of different proximal jams. For two jams in each reach this pattern was not observed: in R1 both of these were located on or near outer meander bend locations and in $\mathrm{R} 2$ both jams comprised key wood pieces staked into the channel at some distance from the bank. 


\section{Vegetation dynamics}

Vegetation cover was highest in the NR reach; increasing slightly from 80 to $90 \%$ over the study period (Figure 7a) but this largely reflects the cover of submerged plants since marginal and emergent vegetation accounted for $20 \%$ total cover or less throughout the period (Figure 7b). Both restored sections showed a considerable increase in vegetation cover between T1 and T2 (84\% increase for R1, 56\% increase for R2) and vegetation cover remained high (70$80 \%$ ) by $\mathrm{T} 3$, with the highest levels recorded in $\mathrm{R} 2$. For R2 there was a substantial increase in the cover of marginal/emergent species following restoration which then declined but remained $>60 \%$ by T3 (Figure $7 \mathrm{~b}$ ). In R1 the cover of marginal and emergent vegetation showed less change through time fluctuating between 40-60\%, and increased plant cover was associated primarily with the expansion of submerged aquatic vegetation (Figure 7c). For NR, the proportion of marginal/emergent vegetation types was similar across surveys, with a slight reduction between $\mathrm{T} 1$ and $\mathrm{T} 2$. Visualisations of vegetation cover in the restored sections (Figure 7c) reveal clustering of marginal and emergent vegetation around the wood jams in $\mathrm{R} 1$ and R2. The areal cover of vegetation is presented according to Ellenberg moisture values for the three reaches $(R 1, R 2, N R)$ in Figure 8, together with species level data for R2. NR was dominated by shallow water species for all three time periods, with a slight reduction in cover between T1 and T3. R1 showed lower variability in the abundance of different Ellenberg groups through time, and a slight reduction in species indicative of damp/marginal environments between T2 and T3. R2 revealed a pronounced increase in cover of shallow water indicator species following restoration (T2), largely Nasturtium officinale and Apium nodiflorum. This subsequently declined (T3), although shallow water species were still most widespread. A more gradual increase in the cover of species representative of marginal and damp environments (Ellenberg scores 6-9) was also noted for R2, reflecting expansions of Myosotis scorpiodes, Phalaris arundinacea, Epilobium hirsutum, Mentha aquatica and Urtica dioca. There was also a distinct difference between the R1 and R2 jams in terms of species richness (Figure 9). In R1 there was either little change or a reduction in richness between T1 
and T3, while in R2, all jams showed increased vegetation species richness compared to the pre-restoration state, although species richness was variable amongst the jams (Figure 9).

\section{DISCUSSION}

The results suggest that large wood (whole trees) can promote channel recovery from overwidening in lowland rivers and highlight some important considerations for restoration design. The initial ecohydromorphological adjustments associated with the wood jam introductions in this study are set against a backdrop of high catchment-derived fine sediment inputs and a trend of aggradation throughout the study section. This is most pronounced in the downstream section (R1) which was restored two years prior to the first field surveys. Pulses or 'slugs' of bed sediment that propagate through river systems have been identified across a range of spatial and temporal scales (Nicholas et al., 1995), with implications for geomorphic diversity (Bartley and Rutherford, 2005) and the ecological success of river restoration schemes (e.g. Howson et al., 2009). Longer-term trends in aggradation, including passage of sediment slugs, cannot be assessed here, but increasing sediment storage throughout the study site (including, to a lesser degree, within the unrestored upstream reach) illustrates the exposure to high inputs of fine sediment that is characteristic of lowland rivers worldwide (Owens et al., 2005). This is an important consideration for ensuring that ecosystem engineering by trees and marginal plants leads to the building of landforms without choking the channel (Gurnell et al., 2010). An additional factor is the interaction between the two restored sections: aggradation in downstream section $\mathrm{R} 1$ is likely to, at least in part, reflect the mobilisation of material following restoration upstream in R2. Despite these reach-scale trends, however, channel response to wood introductions was clearly identifiable.

Where pre-restoration baseline data were available (R2), the introduction of large wood created of new patches of lower shear stress and higher sediment deposition within jams, and patches of higher shear stress and lower sediment deposition in adjacent areas of flow convergence between jams. This is supported by patch-scale suspended sediment release 
experiments at the same field site which demonstrated that diffusion processes were dominant within restored jams, leading to sediment storage, while efficient downstream advection of suspended sediment was observed in areas of flow concentration adjacent to the large wood (Parker et al., 2017). The proportion of sediment stored within wood jams increased by 10\% in the two years following restoration and channel morphological change was characterised by the development of marginal 'benches' of sediment accumulation around wood pieces and bed scour in the flow convergence areas between jams. Two jams appeared less effective in generating this pattern of change, but both of these were anchored some distance from the bank. The capacity for sediment trapping around large wood pieces is likely to have been increased by the complex nature of the jams that comprised multiple wood pieces with branches intact, and by the rapid colonisation of jams by marginal and emergent vegetation species, which act as effective ecosystem engineers in lowland rivers (e.g. Sparganium erectum; Gurnell et al., 2010; Liffen et al., 2011). This may have been facilitated by a more abundant propagule bank that has been identified in marginal bench locations relative to other channel areas at the site (Osei et al., 2015). The increase in vegetation cover reflects a rapid expansion of early-colonising shallow water species ( $N$. officinale and $A$. nodiflorum) in the year following restoration and a more gradual increase (over $2+$ years) in the cover of species characteristic of aquatic-terrestrial transition zones (e.g. M. aquatica, E. hirsutum, $P$. arundinaceae). The latter points to a possible early trend of terrestrialisation of channel margins associated with sediment accumulation, but change was relatively subtle in the two years following restoration and future studies will be required to make this assessment. Likewise, the shallow water species that show a rapid expansion are disturbance-related and may reflect the levels of disturbance associated with the restoration work, especially given that rates of change in vegetation cover observed over longer timescales since restoration in R1 are much slower, and in some cases trends are reversed.

For the reach surveyed 2-4 years following restoration (R1), change over time was more subtle and in some cases trends reversed. Absolute sediment depths increased within wood patches 
through time, but there was no proportional increase in the amount of sediment stored around the jams and hence this may reflect a background trend of aggradation which is most pronounced in this section. Sediment accumulation within marginal benches and bed scour in adjacent areas are clearly identifiable at two jams, but positioning of wood jams in relation to channel planform (outer bends) may have contributed to the reduced effectiveness of two jams in developing pronounced scour and depositional features. The proportion of marginal and emergent vegetation was relatively stable through time and the cover of species indicative of aquatic-terrestrial transitional zones declined after an initial increase. Within individual jams there was either no change or a reduction in cover and species richness over the three year period of study. The differences between the two reaches indicate a possibility that the trajectory of change in R2 may change, but since the style of restoration (proximity of jams, jam dimensions) differed between the two sections, it is difficult to draw direct comparisons. Longer-term monitoring programmes are required to identify whether trajectories of change are persistent, and such programmes should include unrestored control sections to enable comparison of local restoration-induced change with wider catchment influences such as the aggradation trend identified here through the examination of the NR reach.

This study suggests that the reintroduction of large wood can lead to channel recovery towards dimensions closer to those expected under semi-natural (unmodified) conditions. The restoration design increased habitat complexity at the channel margins through a combination of wood pieces with attached branches, and associated aquatic macrophytes and marginal sediment benches. Impacts of the restoration on other aquatic organisms were not assessed here, but multiple important ecological and nature conservation benefits might be expected through the addition of structurally complex marginal habitat and associated food resources for a range of aquatic organisms. For instance, invertebrate biomass and diversity increases were indeed demonstrated following reintroduction of large wood in a $\mathrm{MBACl}$ (multiple beforeafter-control-impact) study across multiple rivers, one of which was our study site (Thompson, 2014; Thompson et al., in review). Similar patterns have also been identified in lowland, fine- 
sediment dominated rivers that are rich in naturally occurring large wood features (Pilotto et al., 2014; 2016). Large wood has also been shown to increase abundance of small body size invertebrates, reflecting its importance in relation to provision of refugia (Thompson, 2014). The response of fish to large wood introduction has been particularly equivocal (Roni et al., 2015) and still needs to be fully assessed for our study river. Nevertheless, based on other UK sites, increases in the amount of deeper water can be expected to have enhanced populations of large brown trout (Salmo trutta) and eel (Anquilla anquilla) (Langford et al., 2012). Further, concentration of flow in central channel areas between jams and consequent bed scour may also improve the quality of key spawning habitat for salmonids (Soulsby et al., 2001). Finally, the densely vegetated river margins associated with fallen trees afford suitable feeding habitat for declining riverine mammals such as water vole (Arvicola amphibious; Moorhouse et al., 2009). More research is required to determine the fuller ecological and conservation implications of river restoration using whole trees, and more work is needed on the links between geomorphology, hydrology and ecology in this context and over longer timescales. Nonetheless our study provides some initial insights into the hydro-geomorphic processes that accompany wood-based restoration design which may help to explain emerging data on biological recovery in restored rivers.

\section{CONCLUSION}

Initial adjustments to restoration using complex large wood features (whole trees) indicate an important role for large wood in river restoration design that includes facilitation of channel narrowing and an increased complexity of marginal and instream habitats. The combined ecosystem engineering effect of wood pieces and colonising aquatic vegetation is a natural characteristic of lowland, low energy rivers and integration of larger-scale wood features into restoration design represents an important opportunity. Such an approach appears to be more effective than more artificial engineered enhancements such as channel narrowing using faggots and backfill or flow deflectors. Further, restoration using large wood can be extremely low-cost, simply requiring felling of riparian trees (where present). With growing emphasis on 
're-wilding' and 'working with natural processes' within the wider river research and conservation community, there may be greater scope and support for more ambitious restoration programmes that include additional ecosystem engineers (e.g. beaver), and thus remove or reduce the need for felling. It is essential that such approaches are fully explored and assessed in order to optimise the benefits to be gained from working with nature.

\section{ACKNOWLEDGEMENTS}

We dedicate this paper to Dave Brady who advocated, planned and undertook the restoration during his role as National Trust Ranger on the Blickling Estate. On his retirement Dave leaves an important legacy and he has been a true champion for the benefits of river 're-wilding'. Thanks to Dave and the National Trust for access to the field site, much background information and for postponing the second phase of restoration to allow for baseline data collection. The research was supported by the Earth Surface Science research theme in the School of Geography at QMUL (Harvey and Henshaw), a British Society for Geomorphology Research Grant ('Assessing the long term influence of wood on the hydromorphology of a lowland UK river', to Chris Parker) and a University of the West of England Early Career Research Starter Grant (to Chris Parker).

\section{REFERENCES}

Abbe TB, Montgomery DR. 1996. Large woody debris jams, channel hydraulics and habitat formation in large rivers. Regulated Rivers: Research and Management 12: 201-221.

Benke AC, Henry III RL, Gillespie DM, Hunter RJ. 1985. Importance of snag habitat for animal production in southeastern streams. Fisheries 10:8-13.

Bernhardt ES, Palmer MA, Allan JD, Alexander G, Barnas K, Brooks S, Carr J, Clayton S, Dahm C, Follstad-Shah J, Galat D, Gloss S, Goodwin P, Hart D, Hassett B, Jenkinson R, Katz 
S, Kondolf GM, Lake PS, Lave R, Meyer JL, O'Donnell TK, Pagano L, Powell B, Sudduth E. 2005. Synthesizing U.S. river restoration efforts. Science 308: 636-637.

Bartley R, Rutherfurd I. 2005. Measuring the reach-scale geomorphic diversity of streams: application to a stream disturbed by a sediment slug. Regulated Rivers: Research and Management 21: 39-59.

Cashman MJ. 2015. The effect of large wood on river physical habitat and nutritional dynamics. Unpublished PhD Thesis, School of Geography, Queen Mary University of London.

Cashman MJ, Pilotto F, Harvey GL, Wharton G, Pusch MT. 2016. Combined stable isotope and fatty acid analyses demonstrate that large wood increases the autochthonous trophic base of a macroinvertebrate assemblage. Freshwater Biology. DOI: 10.1111/fwb.12727.

Chin A, Daniels MD, Urban MA, Piégay H, Gregory KJ, Bigler W, Butt AZ, Grable JL, Gregory SV, Lafrenz M, Laurencio LR, Wohl E. 2008. Perceptions of wood in rivers and challenges for stream restoration in the United States. Environmental Management 41: 893-903.

Collins BD, Montgomery DR, Fetherston KL, Abbe TB. 2012. The floodplain large-wood cycle hypothesis: A mechanism for the physical and biotic structuring of temperate forested alluvial valleys in the North Pacific coastal ecoregion. Geomorphology 139-140: 460-470

Environment Agency. 2010. Working with Natural Processes to Manage Flood and Coastal Erosion Risk. Environment Agency Guidance Document.

Erskine WD, Webb AA. 2003. Desnagging to resnagging: new directions in river rehabilitation in southeastern Australia. River Research and Applications 19: 233-249. 
Erskine W, Keene A, Bush R, Cheetham M, Chalmers A. 2012. Influence of riparian vegetation on channel widening and subsequent contraction on a sand-bed stream since European settlement: Widden Brook, Australia. Geomorphology 147-148: 102-114.

European Parliament. 2000. Directive 2000/60/EC of the European Parliament and of the Council of 23 October 2000: establishing a framework for community action in the field of water policy. Brussels, Belgium

Gibbons DR. 1990. Fish in the forest - Large woody debris in streams: A new management approach to fish habitat. U.S. Department of Agriculture, Forest Service, Alaska Region, Juneau, Alaska (USA).

Gippel CJ, O’Neill IC, Finlayson BL and Schnatz I. 1996. Hydraulic guidelines for the reintroduction and management of large woody debris in lowland rivers. Regulated Rivers: Research and Management 12: 223-236.

Gregory KJ, Davis RJ. 1992. Coarse woody debris in stream channels in relation to river channel management in woodland areas. Regulated Rivers: Research and Management 7: 117-136.

Gregory KJ, Gurnell AM, Hill CT. 1985. The permanence of debris dams related to river channel processes. Hydrological Sciences Journal 30: 371-381.

Gregory SV,Boyer KL and Gurnell AM (eds) (2003) The ecology and management of wood in world rivers. American Fisheries Society, Symposium 37, Bethesda, Maryland. 
Gurnell AM, Gregory KJ, and Petts GE. 1995. The role of a coarse woody debris in forest aquatic habitats: Implications for management. Aquatic Conservation: Marine and Freshwater Ecosystems 5:143-166.

Gurnell AM, Petts GE, Hannah DM, Smith BPG, Edwards PJ, Kollman J, Ward JV, Tockner K. 2001. Riparian vegetation and island formation along the gravel-bed Fiume Tagliamento, Italy. Earth Surface Processes and Landforms 26(1): 31-62.

Gurnell AM, Piegay H, Swanson FJ, Gregory SV. 2002. Large wood and fluvial processes. Freshwater Biology 47(4): 601-619.

Gurnell A, Tockner K, Edwards P, Petts G. 2005. Effects of deposited wood on biocomplexity of river corridors. Frontiers in Ecology and the Environment 3: 377-382.

Gurnell A. 2014. Plants as river system engineers. Earth Surface Processes and Landforms 39: 4-25.

Gurnell AM, O'Hare JM, O'Hare MT, Dunbar MJ, Scarlett PM. 2010. An exploration of associations between assemblages of aquatic plant morphotypes and channel geomorphological properties within British rivers. Geomorphology 116: 135-144.

Harrison SSC, Harris ITB, Armitage PD. 1999. The role of bankside habitat in river ecology: the importance of riparian and marginal vegetation of the distribution and abundance of aquatic invertebrates. R\&D Technical Report W198. Environment Agency.

Hill MO, Mountford JO, Roy DB, Bunce RGH. 1999. Ellenberg's indicator values for British plants. ECOFACT Volume 2 Technical Annex. Huntingdon, Institute of Terrestrial Ecology, 46pp. (ECOFACT, 2a). 
Hill MO, Preston CD, Roy DB. 2004. PLANTATT - attributes of British and Irish Plants: status, size, life history, geography and habitats. Centre for Ecology and Hydrology, Huntingdon.

Howson TJ, Robson BJ, Mitchell, BD. 2009. Fish assemblage response to rehabilitation of a sand-slugged lowland river. River Research and Applications 25: 1251-1267.

Kail J, Hering D, Muhar S, Gerhard M and Preis S. 2007. The use of large wood in stream restoration: experiences from 50 projects in Germany and Austria. Journal of Applied Ecology 44: 1145-1155.

Keller EA, Swanson FJ. 1979. Effects of large organic material on channel form and fluvial processes. Earth Surface Processes and Landforms 4:361-380.

Krause S, Klaar M, Hannah DM, Mant J, Bridgeman J, Trimmer M, Manning-Jones S. 2014. The potential of large woody debris to alter biogeochemical processes and ecosystem services in lowland rivers. WIREs Water 2014, 1: 263-275.

Langford TEL, Langford J, Hawkins SJ. 2012. Conflicting effects of woody debris on stream fish populations: implications for management. Freshwater Biology 77: 1096-1111.

Larson MG, Booth DB and Morley SA. 2001. Effectiveness of large woody debris in stream rehabilitation projects in urban basins. Ecological engineering 18: 211-226.

Liffen T, Gurnell AM, O’Hare M, Pollen-Bankhead N, Simon A. 2011. Biomechanical properties of the emergent macrophyte Sparganium erectum: implications for landform development in low energy rivers. Ecological Engineering 37: 1925-1931. 
Lisle TE, Hilton S. 1992. The volume of fine sediment in pools: an index of sediment supply in gravel-bed streams. Water Resources Bulletin 28(2): 371-383.

Magilligan FJ, Nislow KH, Fisher GB, Wright J, Mackey G and Laser M. 2008. The geomorphic function and characteristics of large woody debris in low gradient rivers, coastal Maine, USA. Geomorphology 97: 467-482.

Mainstone CP (1999) Chalk rivers: nature conservation and management. Water Research Centre. Produced on behalf of English Nature and the Environment Agency.

Millenium Ecosystem Assessment. 2005. Ecosystems and Human Well-being: Synthesis. Island Press, Washington, DC.

Moorhouse TP, Gelling M, Macdonald DW. 2009. Effects of habitat quality upon reintroduction success in water voles: Evidence from a replicated experiment. Biological Conservation 142: 53-60.

Morandi B, Piégay H, Lamouroux N, Vaudor L. 2014. How is success or failure in river restoration projects evaluated? Feedback from French restoration projects. Journal of Environmental Management 137:178-188.

Nakamura F, Swanson FJ. 2003. Dynamics of wood in rivers in the context of ecological disturbance. In: Gregory SV, Boyer KL, Gurnell AM (eds) The Ecology and Management of Wood in World Rivers. American Fisheries Society Symposium 37, Bethesda, Maryland, USA. pp. $279-297$

National River Flow Archive. Undated. Daily River Flow Data. Available at: http://nrfa.ceh.ac.uk/. Last accessed 02/03/2017. 
Navarro LM and Pereira HM. 2012. Rewilding abandoned landscapes in Europe. Ecosystems 15: $900-912$

Nicholas AP, Ashworth PJ, Kirkby MJ, Macklin MG and Murray T. 1995. Sediment slugs: largescale fluctuations in fluvial sediment transport rates and storage volumes. Progress in Physical Geography 19: 500-519.

Osei N, Harvey GL and Gurnell AM. 2015. The early impact of large wood introduction on the morphology and sediment characteristics of a lowland river. Limnologica 54:33-43.

Owens PN, Batalla RJ, Collins AJ, Gomez B, Hicks DM, Horowitz AJ, Kondolf GM, Marden M, Page MJ, Peacock DH, Petticrew EL, Salomons W, Trustrum NA. 2005. Fine-grained sediment in river systems: environmental significance and management issues. River Research and Applications 21: 693-717.

Parker C, Henshaw AJ, Harvey GL, Sayer CD (2017) Reintroduced large wood modifies fine sediment dynamics in an over-widened lowland river channel. Earth Surface Processes and Landforms. DOI: 10.1002/esp.4123.

Palmer MA, Menninger HL and Bernhardt E (2010) River restoration habitat heterogeneity and biodiversity: a failure of theory or practice? Freshwater Biology 55: 205-222.

Piégay H, Gregory KJ, Bondarev V, Chin A, Dahlstrom N, Elosegi A, Gregory SV, Joshi V, Mutz M, Rinaldi M, Wyzga B, Zawiejska J. 2005. Public perception as a barrier to introducing wood in rivers for restoration purposes. Environmental Management 36: 665-674. 
Pilotto F, Bertoncin A, Harvey GL, Wharton G, Pusch MT. 2014. Diversification of stream invertebrate communities by large Wood. Freshwater Biology 59: 2571-2583.

Pilotto F, Harvey GL, Wharton G, Pusch MT. 2016. Simple large wood structures promote hydromorphological heterogeneity and benthic macroinvertebrate diversity in low-gradient rivers. Aquatic Sciences 78: 755-766.

River Restoration Centre. 2013. Manual of River Restoration Techniques. Introducing Sinuosity to a Straightened Channel 5.7 Felling trees into a channel to create flow diversity (River Bure). Available at:

http://www.therrc.co.uk/MOT/Final Versions \%28Secure\%29/5.7 Bure.pdf, Accessed 23/03/2016.

Roni P, Beechie T, Pess G and Hanson K. 2015. Wood placement in river restoration: fact, fiction and future direction. Canadian Journal of Fisheries and Aquatic Sciences 72: 466478.

Soulsby C. Youngson AF, Moir HJ, Malcolm IA. 2001. Fine sediment influence on salmonid spawning habitat in a lowland agricultural stream: a preliminary assessment. Science of the Total Environment 265: 295-307.

Thevenet A, Citterio A, Piégay H. 1998. A new methodology for the assessment of large woody debris accumulations on highly modified rivers (example of two French Piedmont rivers). Regulated Rivers: Research and Management 14: 467-483.

Thompson MSA, Brooks SJ, Sayer CD, Woodward G, Axmacher JC, Perkins D and Gray C. (in prep). Large woody debris 'rewilding' restores biodiversity in riverine food webs. 
Thompson MSA (2014). The Effect of Large Woody Debris Restoration on Stream

Ecosystems. PhD Thesis, unpublished PhD Thesis. Department of Geography, University of London and Department of Life Sciences, Natural History Museum.

Thompson DM, Stull GN, 2002. The development and historic use of habitat structures in channel restoration in the United States: the grand experiment in fisheries management. Geographie physique et Quaternaire 56:45-60.

Wallerstein NP, Thorne CR. 2004. Influence of large woody debris on morphological evolution of incised, sand-bed channels. Geomorphology 57:53-73.

Watts K. 2006. British forest landscapes: The legacy of woodland fragmentation. Quarterly Journal of Forestry 100(4): 273-279.

Wilcock PR. 1996. Estimating local bed shear stress from velocity observations. Water Resources Research 32(11):3361-3366.

O’Neill R. and Hughes K. 2014. The State of England's Chalk Sreams. WWF-UK Report. Available at:

http://assets.wwf.org.uk/downloads/wwf chalkstreamreport jan15 forweb.pdf? ga=1.15782 $\underline{2386.922287243 .1491216382}$

Wyzga B, Zawiejska J, Lay YL. 2009. Influence of academic education on the perception of wood in watercourses, Journal of Environmental Management 90: 587-603

Wohl E. 2015. Of wood and rivers: bridging the perception gap. WIREs Water 2: 167-176. 
Table 1: Wood jam characteristics for the two study reaches.

\begin{tabular}{|c|c|c|c|c|c|c|c|}
\hline & Jam & $\begin{array}{l}\text { No. } \\
\text { wood } \\
\text { pieces }\end{array}$ & $\begin{array}{c}\text { Max } \\
\text { piece } \\
\text { length } \\
(\mathrm{m})\end{array}$ & $\begin{array}{c}\text { Max } \\
\text { piece } \\
\text { diamete } \\
\mathbf{r}(\mathbf{m})\end{array}$ & $\begin{array}{c}\text { Jam } \\
\text { orientation } \\
\left({ }^{\circ}\right)\end{array}$ & $\begin{array}{l}\text { Positioning } \\
\text { (channel } \\
\text { planform) }\end{array}$ & Anchoring \\
\hline \multirow{4}{*}{$\overline{\check{r}}$} & $\mathrm{R} 1 \mathrm{a}$ & 1 & 10.2 & 0.35 & 25 & $\begin{array}{l}\text { Upstream of } \\
\text { outer bend }\end{array}$ & $\begin{array}{l}\text { Anchored on } \\
\text { bank }\end{array}$ \\
\hline & $R 1 b$ & 2 & 13.9 & 0.36 & 155 & $\begin{array}{l}\text { Downstream } \\
\text { of outer bend }\end{array}$ & $\begin{array}{l}\text { Staked in } \\
\text { channel }\end{array}$ \\
\hline & R1c & 4 & 13.4 & 0.35 & 145 & $\begin{array}{l}\text { On outer } \\
\text { bend }\end{array}$ & $\begin{array}{l}\text { Anchored on } \\
\text { bank }\end{array}$ \\
\hline & R1d & 4 & 11.5 & 0.5 & 5 & $\begin{array}{l}\text { Upstream of } \\
\text { inside bend }\end{array}$ & $\begin{array}{l}\text { Anchored on } \\
\text { bank }\end{array}$ \\
\hline \multirow{7}{*}{$\widetilde{\simeq}$} & $\mathrm{R} 2 \mathrm{a}$ & 2 & 10 & 0.5 & 20 & $\begin{array}{l}\text { Straight } \\
\text { section }\end{array}$ & $\begin{array}{l}\text { Staked in } \\
\text { channel }\end{array}$ \\
\hline & $\mathrm{R} 2 \mathrm{~b}$ & 3 & 14.2 & 0.41 & 15 & $\begin{array}{l}\text { Straight } \\
\text { section }\end{array}$ & $\begin{array}{l}\text { Anchored on } \\
\text { bank }\end{array}$ \\
\hline & $\mathrm{R} 2 \mathrm{c}$ & 3 & 16.2 & 0.5 & 10 & $\begin{array}{l}\text { Straight } \\
\text { section }\end{array}$ & $\begin{array}{l}\text { Staked in } \\
\text { channel }\end{array}$ \\
\hline & $\mathrm{R} 2 \mathrm{~d}$ & 5 & 19 & 0.65 & 20 & $\begin{array}{l}\text { Straight } \\
\text { section }\end{array}$ & $\begin{array}{l}\text { Anchored on } \\
\text { bank }\end{array}$ \\
\hline & $\mathrm{R} 2 \mathrm{e}$ & 3 & 15.2 & 0.29 & 170 & $\begin{array}{l}\text { Straight } \\
\text { section }\end{array}$ & $\begin{array}{l}\text { Staked in } \\
\text { channel }\end{array}$ \\
\hline & $R 2 f$ & 3 & 8.2 & 0.35 & 150 & $\begin{array}{l}\text { Straight } \\
\text { section }\end{array}$ & $\begin{array}{l}\text { Staked in } \\
\text { channel }\end{array}$ \\
\hline & $\mathrm{R} 2 \mathrm{~g}$ & 3 & 10.2 & 0.59 & 20 & $\begin{array}{l}\text { Straight } \\
\text { section }\end{array}$ & $\begin{array}{l}\text { Anchored on } \\
\text { bank }\end{array}$ \\
\hline
\end{tabular}




\section{FIGURES}

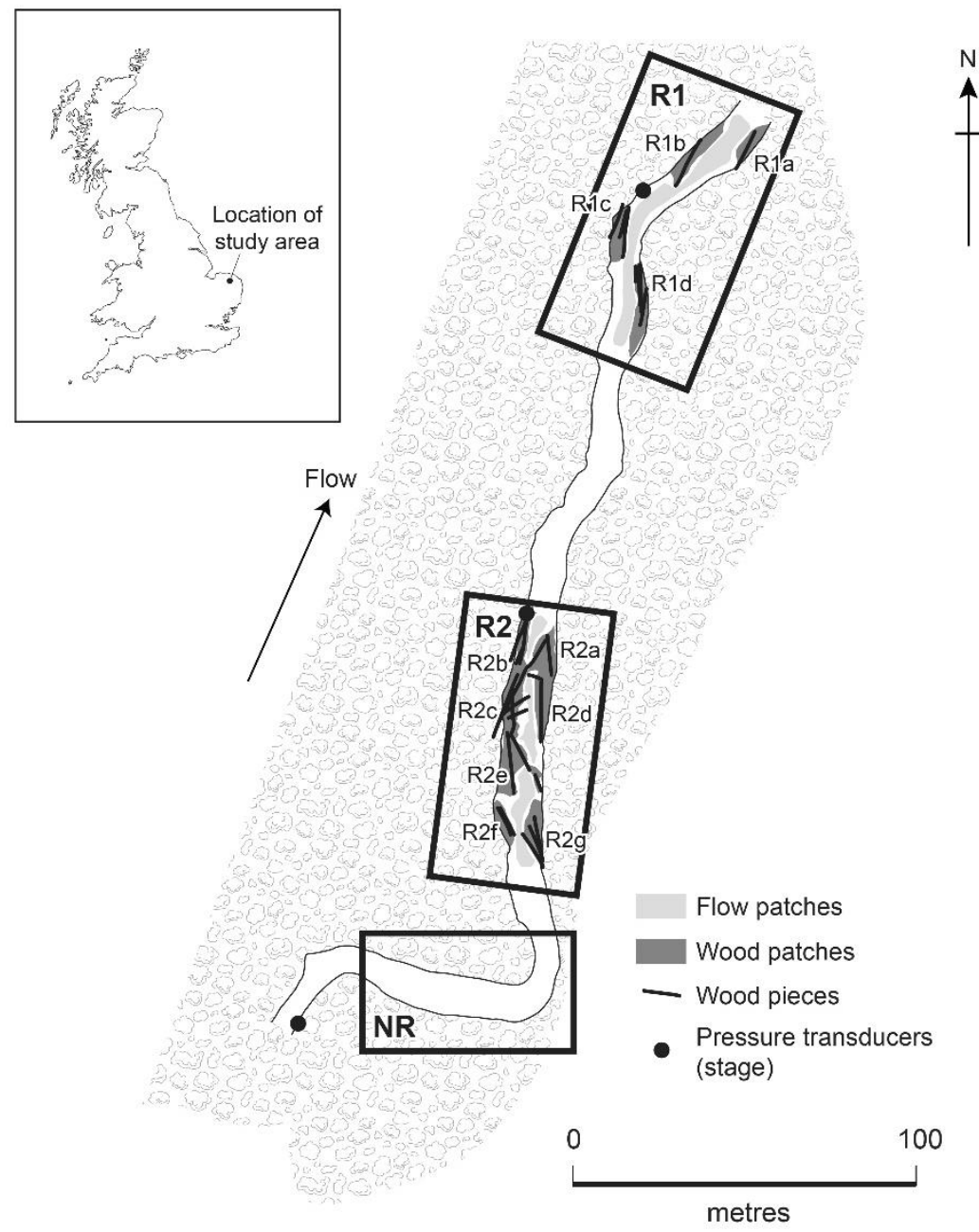

Figure 1: Location of the study reaches showing position of wood jams, instrumentation and sampling patches. Boxes show the upstream and downstream extent of cross sections used to capture data for each reach. 

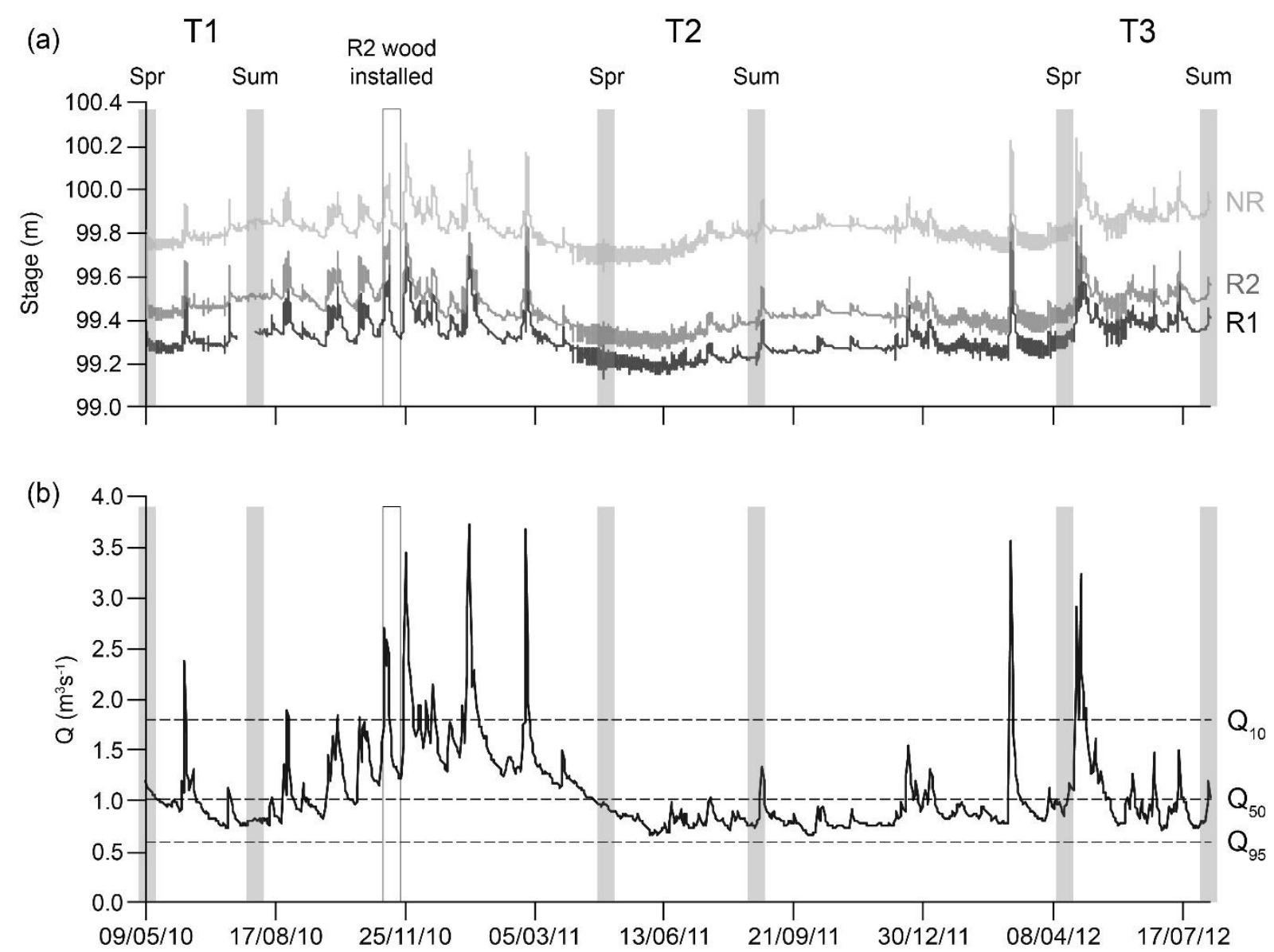

Figure 2: Hydrological time series for the period of record showing (a) measured stage at the field site derived from three pressure transducers located in $\mathrm{R} 1, \mathrm{R} 2$ and $\mathrm{NR}$ reaches (see Figure 1) and (b) gauged $Q$ at Ingworth. Vertical shading shows the timing of field surveys (spring and summer for each survey year). Horizontal dashed lines in (b) represent the $Q_{10}$, $Q_{50}$ and $Q_{95}$ flows for the period 1959-2015 (based on data from the National River Flow Archive, undated). 
(a)

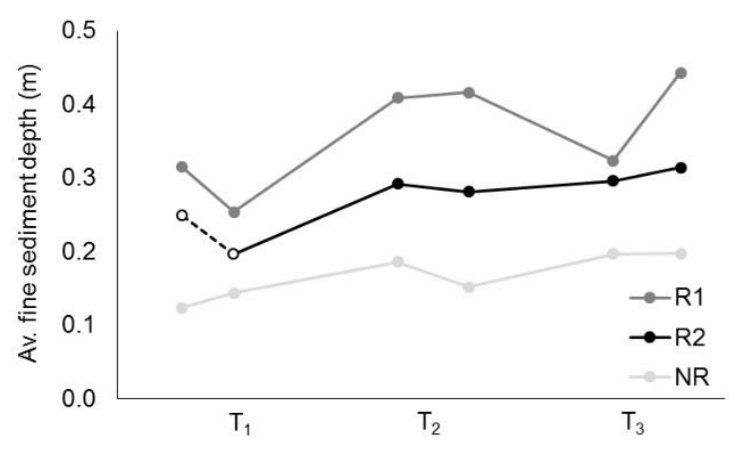

(b)

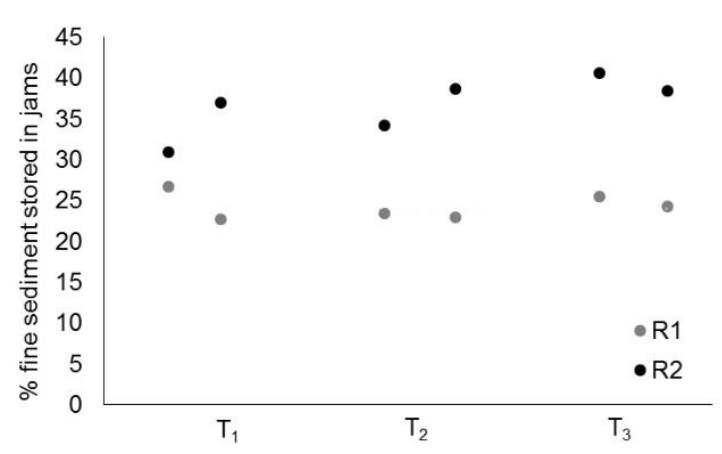

Figure 3: (a) change in average sediment depth through time for each reach and (b) proportion of fine sediment stored within jams. In (a) for R2, open circles and dashed lines highlight pre-restoration data, while closed circles and solid lines represent post-restoration data. 


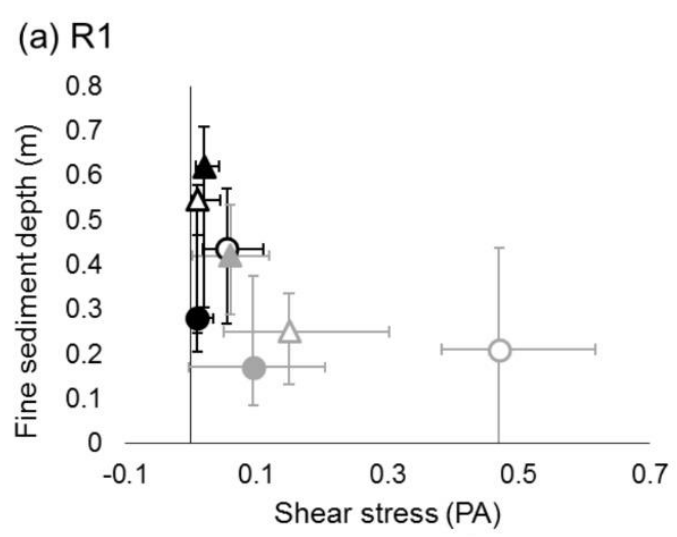

(b) R2 (pre-restoration)

(c) R2 (post-restoration)
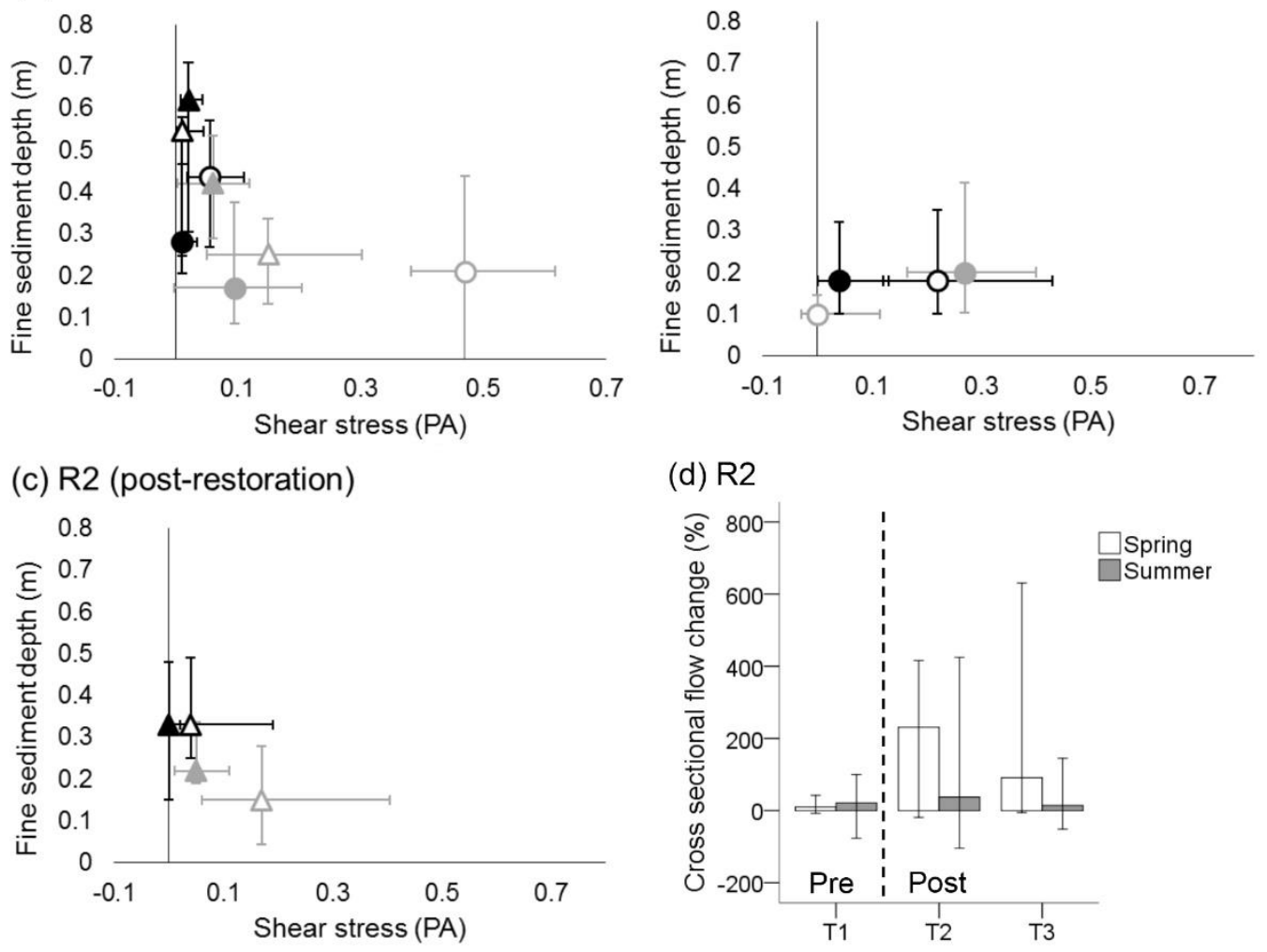

(d) R2

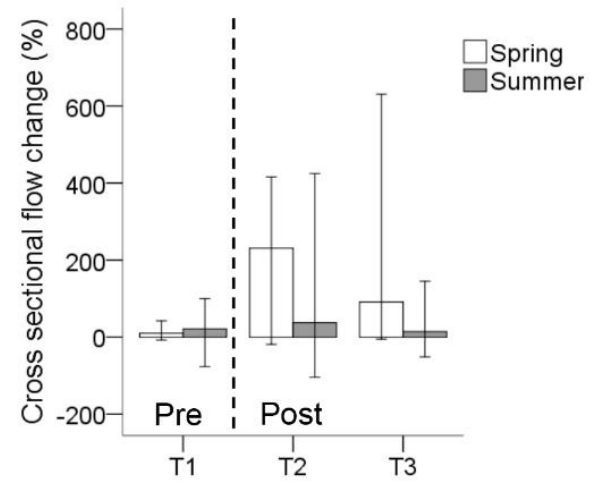

Figure 4: Fine sediment depth and shear stress (median and interquartile range) for wood and concentrated flow patches for the restored reaches for spring and summer surveys in $\mathrm{T} 1$ and T3 $(\mathrm{Q}=0.49-0.64 \mathrm{m3s}-1)$ : (a) shows data for $\mathrm{R} 1$, (b) shows data for $\mathrm{R} 2$ pre-restoration and (c) shows data for R2 post restoration. Symbols: black= wood, grey= flow, closed = summer; open = spring; circles $=\mathrm{T} 1$ and triangles $=\mathrm{T} 3$ ). $(\mathrm{c})$ shows percentage change in flow velocity between marginal and central channel areas for $\mathrm{R} 2$ pre and post restoration. 


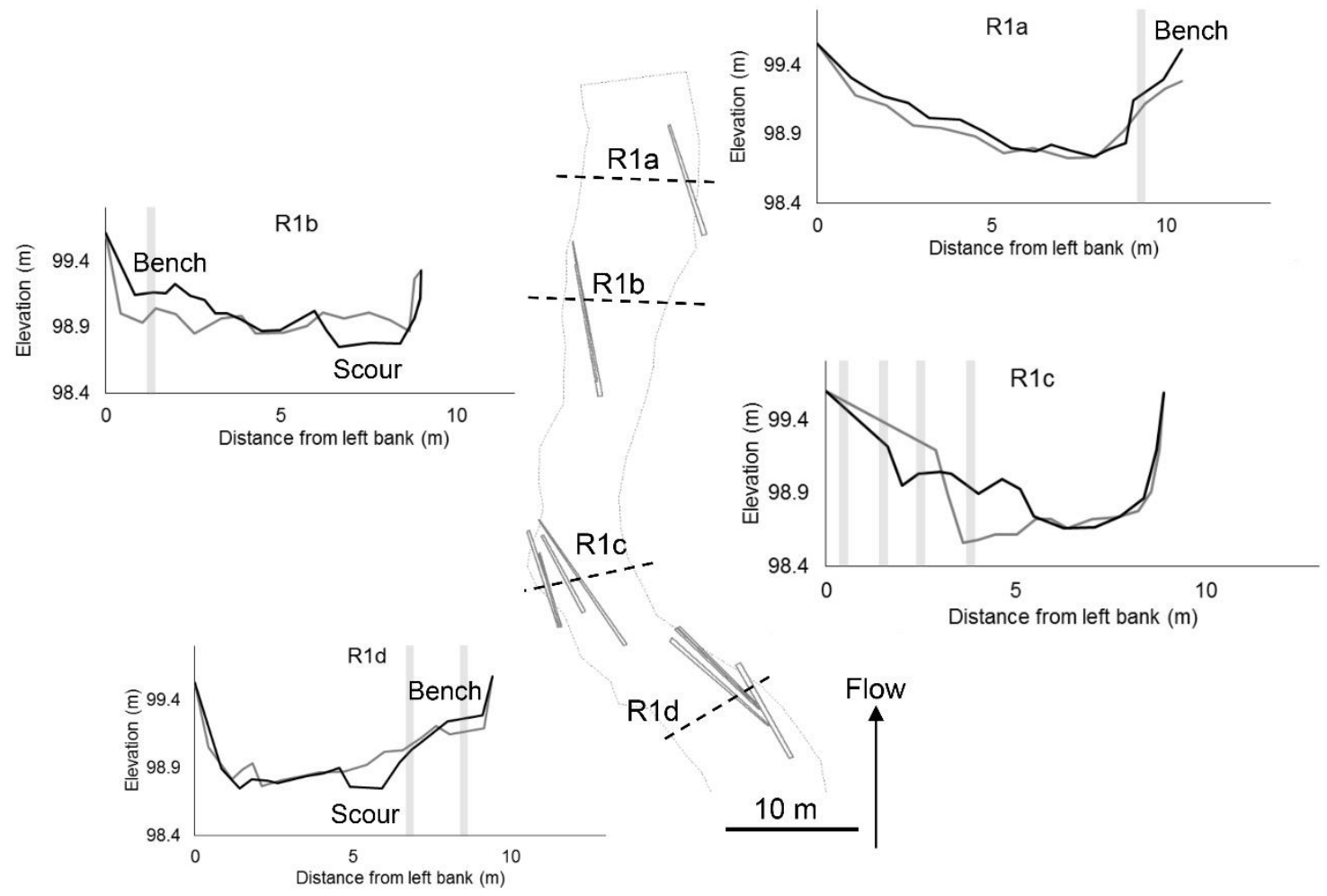

Figure 5: Cross sectional bed elevation profiles for jams in R1 for T1 (grey lines) and T2 (black lines). 

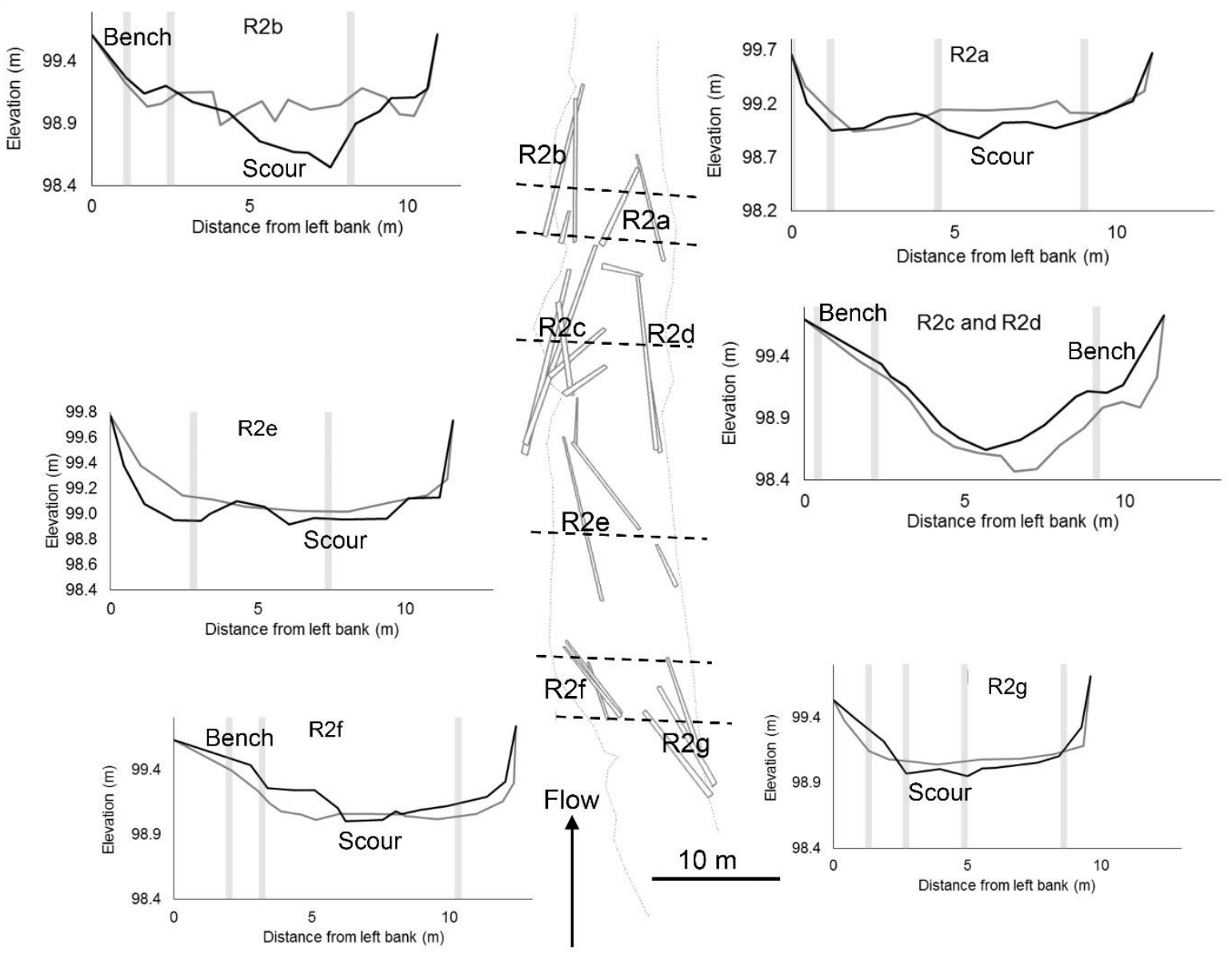

Distance from left bank (m)
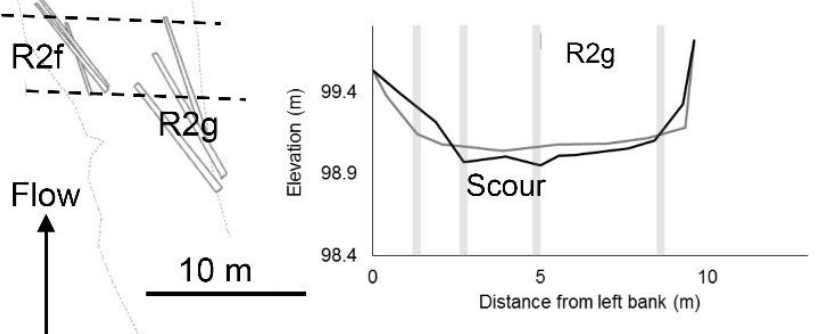

Figure 6: Cross sectional bed elevation profiles for jams in R2 for T1 (grey lines) and T2 (black lines). 
(a)

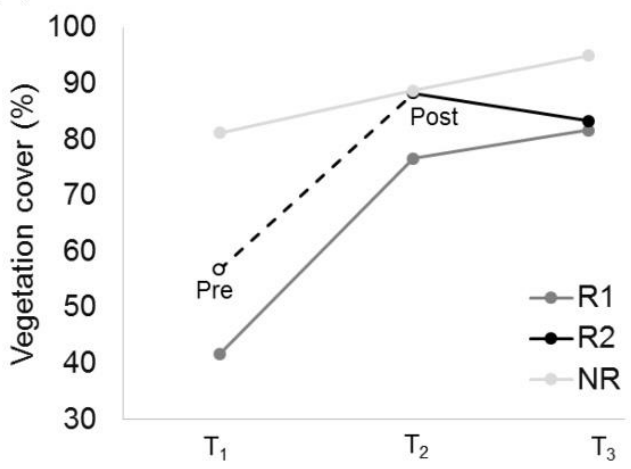

(b)

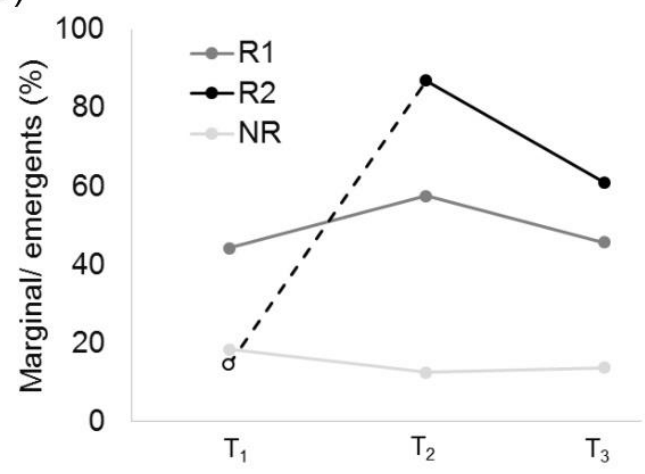

(d)

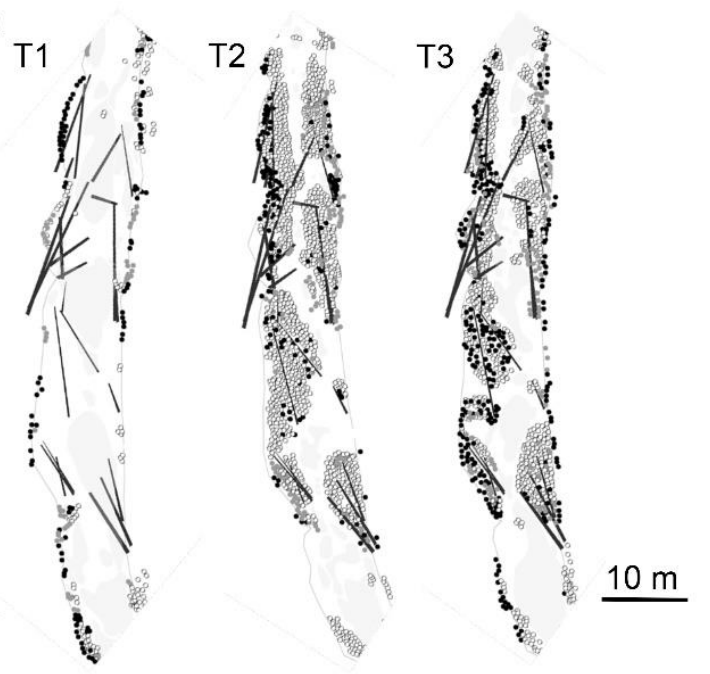

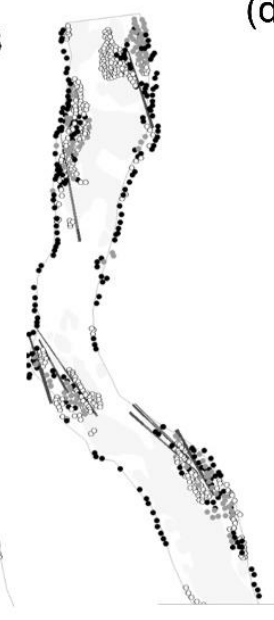

(c)

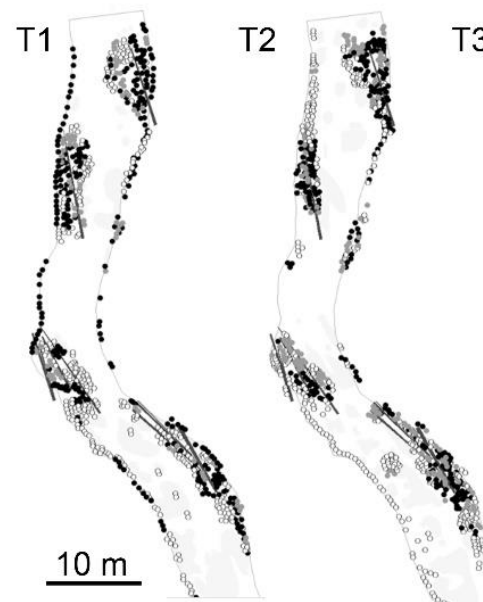

Ellenberg score 10-11

Ellenberg score 9

- Ellenberg score 6-8

Submerged macrophytes

Figure 7: (a) overall percentage vegetation cover based on point sampling for each reach;

(b) percentage areal cover of marginal/emergent vegetation derived from digitised field maps and (c) visualisations of vegetation types coded by Ellenberg moisture scores for T1, T2 and T3. In (a) and (b) for R2, open circles and dashed lines highlight pre-restoration data, while closed circles and solid lines represent post-restoration data. 

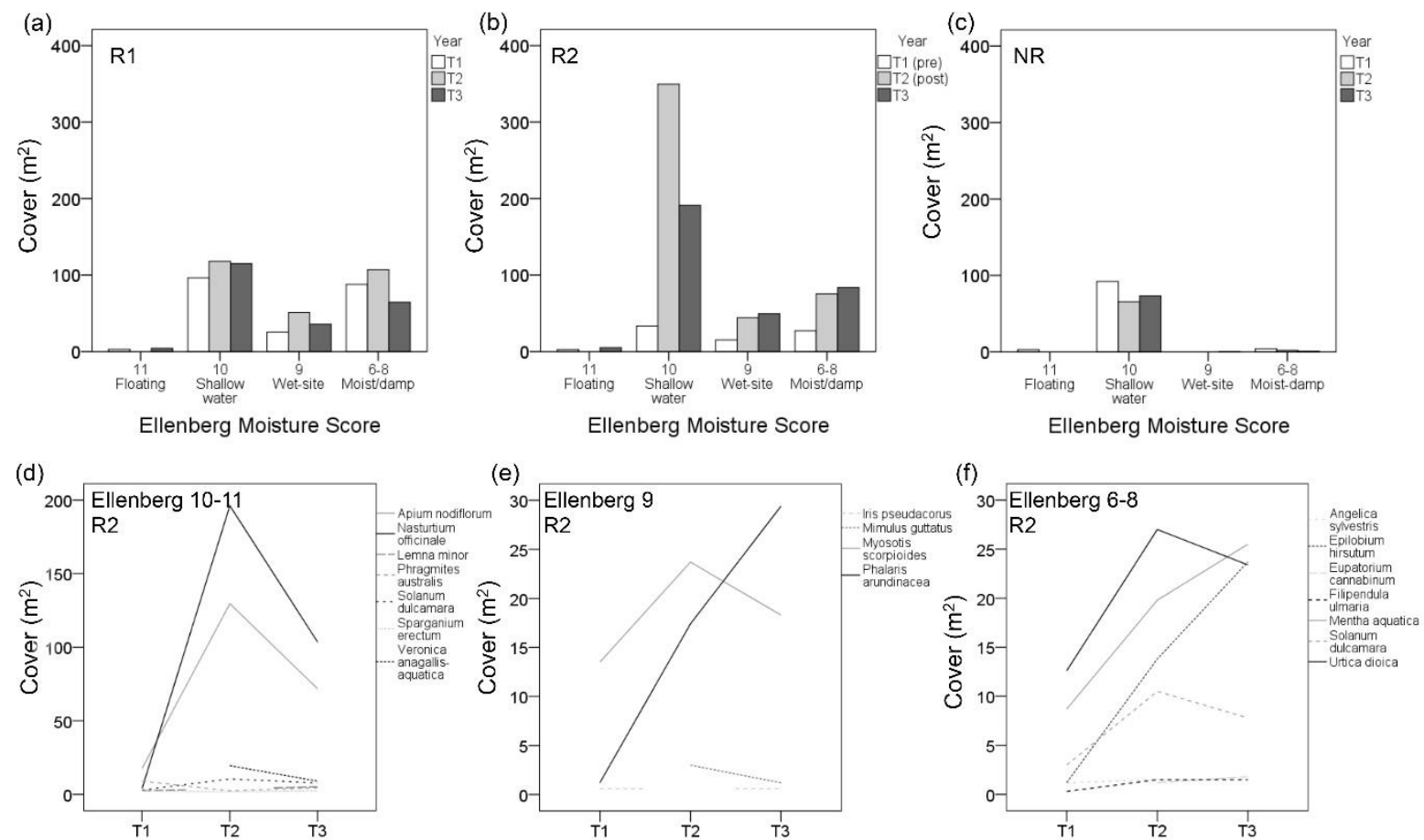

Figure 8: Areal cover of Ellenberg moisture score groupings for (a) R1, (b) R2 and (c) NR. (d) to (f) show change in cover for individual species, grouped according to Ellenberg scores (species $>5 \mathrm{~m}^{2}$ cover only).

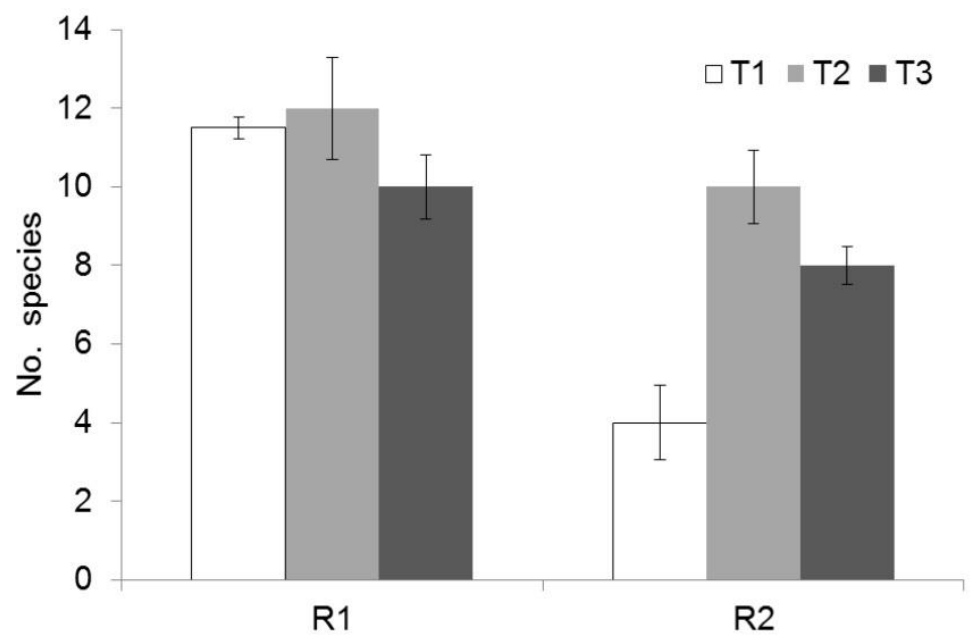

Figure 9: Average change in species richness between T1 and T3 for each individual jam. Error bars show standard deviation. For R2, $\mathrm{T} 1$ data refer to the areas in R2 where jams were later introduced. 


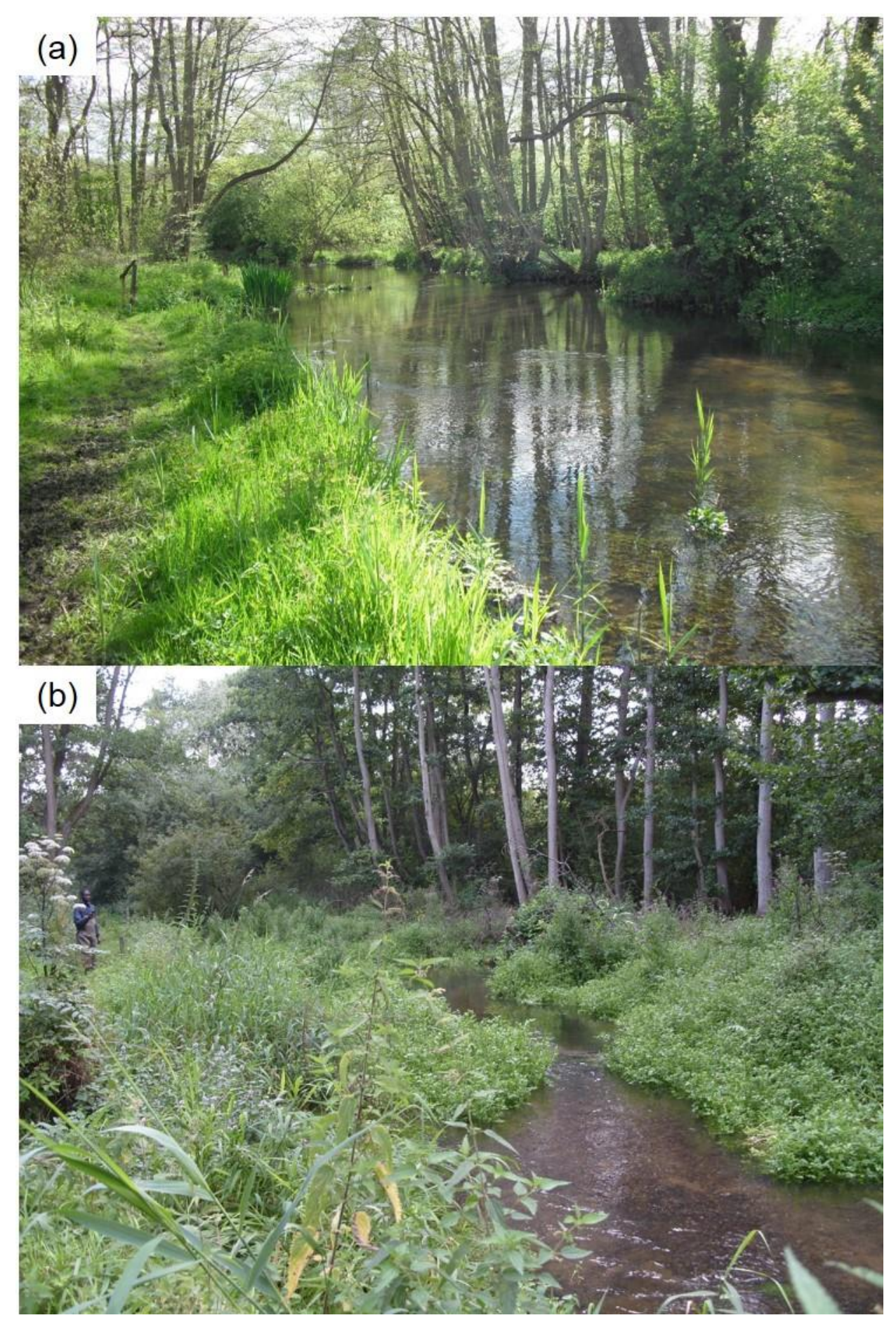

Figure 10: Photographs of the reach R2 (a) before and (b) after restoration (T1). 